\title{
Variasi Marka Kualitatif pada Ayam Kokok Balenggek ; Plasma Nutfah 'Ayam Penyanyi' Sumatera Barat
}

\section{Variations of Qualitative Marker on Kokok Balenggek Chicken; 'A Genuine Singer Rooster' Germ Plasm in West Sumatera}

\author{
Rusfidra \\ Fakultas Peternakan Universitas Andalas \\ Kampus Unand Limau Manis Padang, 25163 \\ e-mail : rusfidra@gmail.com \\ (Diterima : 20 Juni 2014 , Disetujui : 20 September 2014)
}

\begin{abstract}
ABSTRAK
Marka kualitatif pada Ayam Kokok Balenggek (AKB) perlu diidentifikasi sebagai penciri suatu bangsa pada AKB. Penelitian ini bertujuan untuk mengidentifikasi beberapa marka kualitatif pada AKB. Penelitian dilakukan di kandang penangkaran AKB Kinantan Bagombak, Kota Solok, Sumatera Barat. Penelitian dilakukan dengan metode survei dan pengumpulan data dilakukan secara sensus. Parameter yang diamati adalah morfologi bulu, distribusi bulu, warna ear lobe, dan variasi bentuk kaki. Hasil penelitian menunjukkan bahwa marka kualitatif morfologi bulu pada AKB adalah bulu normal (100\%), distribusi bulu adalah bulu normal (100\%), warna ear lobe bervariasi dari merah $(74,02 \%)$, putih $(19,85 \%)$ dan putih kemerah-merahan $(6,13 \%)$. Variasi bentuk kaki AKB adalah normal (94,81\%), dan AKB berkaki pendek/creeper (5,19\%). Untuk pengembangan lebih lanjut usaha peternakan Kinantan Bagombak sebagai salah satu kandang penangkaran secara ek-situ di Sumatra Barat, sebaiknya AKB yang dikembangkan adalah AKB yang memiliki morfologi bulu normal, distribusi bulu normal, warna ear lobe merah, dan variasi bentuk kaki normal.
\end{abstract}

Kata kunci : morfologi bulu, distribusi bulu, ear lobe, variasi bentuk kaki, AKB

\section{ABSTRACT}

The qualitative markers on Kokok Balenggek cock are urgent to identify the character of this chicken. A survey was conducted at Kinantan Bagombak Captive Breeding Farm in Solok City, West Sumatra to identify the qualitative characters of this genuinely local breed chicken. This study was aimed at collecting baseline data on qualitative marker of Kokok Balenggek as a song fowl breed. Using census approach, fifty cocks of Kokok Balenggek chicken were identified for the study purpose. Traits indicators included following aspects; feather morphology, feather distribution, ear lobe color, and variation of skeletal form. The results showed that $100 \%$ of feather morphology was normal, feather distribution was normal (100\%), variation of skeletal form was normal (94.81\%) and creeper (5.19\%). Earlobe color has three variations; red (74.02 $\%)$, white $(19.85 \%)$, and red with white basis $(6.13 \%)$. Thus all traits indicator were normal. In the future, Kokok Balenggek development priority should be focused on a normal path with red in color of its earlobe.

Key word: feather morphology, feather distribution, ear lobe color, variation of skeletal.

\section{PENDAHULUAN}

Ternak unggas sangat besar manfaatnya terhadap kepentingan umat manusia, terutama sebagai sumber pangan hewani (daging dan telur). Selain itu, ternak sangat penting perannya sebagai sumber pendapatan, tabungan hi- dup (bio investasi), tenaga kerja, transportasi, penghasil biogas, produsen pupuk organik, dan sebagai hewan kesayangan (Rusfidra, 2004; Tangka et al., 2000). Oleh karena itu, Han (1999); Van Der Zijpp (2000) 
menyatakan pentingnya peranan ternak dalam peningkatan kualitas hidup manusia.

Ayam kampung merupakan salah satu jenis ayam lokal yang banyak dipelihara masyarakat Indonesia. Disamping populer sebagai penghasil daging dan telur, ayam lokal dapat dimanfaatkan sebagai ayam hias, ayam petarung dan ayam penyanyi. Ayam lokal yang memiliki suara kokok merdu sebaiknya dikembangkan sebagai ayam penyanyi. Ayam lokal yang potensial sebagai ayam penyanyi adalah Ayam Kokok Balenggek, Ayam Pelung dan Ayam Bekisar dan Ayam Gaga (Ayam Ketawa). Keempat bangsa ayam lokal tersebut memiliki suara kokok merdu, enak didengar dan digemari oleh banyak hobiis ayam penyanyi (Rusfidra, 2014).

Kemerduan dan keunikan suara kokok AKB diduga satu-satunya bangsa ayam dengan tipe kokok balenggek di dunia (Rusfidra, 2004; Rusfidra, 2014). AKB memiliki posisi yang tinggi bagi masyarakat suku Minangkabau (Fumihito et al., 1996). Pada tahun 2011 AKB ditetapkan oleh Kementerian Pertanian sebagai rumpun ternak nasional (Rusfidra, 2014; Rusfidra et al., 2014a; 2014b). Popularitas AKB sebagai ayam penyanyi di Sumatera Barat dalam lima tahun terakhir semakin meningkat karena adanya konteskontes yang diselenggarakan oleh pemerintah dan para penggemarnya (Rusfidra, 2014).

Saat ini di daerah sentra populasi, AKB makin berkurang karena banyak AKB yang dijual ke luar daerah sentra, bahkan AKB yang memiliki suara kokok ayam panjang (banyak lenggek) makin sulit dijumpai di daerah asalnya di Kecamatan Tigo Lurah, Kabupaten Solok. Selain itu, populasi AKB menurun drastis karena serangan penyakit ND (Newcastle disease) serta masih terbatasnya kontes AKB. Berdasarkan kondisi tersebut, maka perlu dilakukan upaya untuk menjaga kelestarian AKB agar tidak punah, baik konservasi di daerah sentra (in-situ), maupun di luar daerah sentra (ek-situ) (Rusfidra et al., 2012).

Keragaman genetik sangat diperlukan dalam upaya pemuliaan ternak, karena dengan diketahuinya keragaman genetik ternak, maka dimungkinkan untuk membentuk bangsa ternak baru melalui seleksi dan sistem perkawinan. Marka kualitatif pada ayam dapat dilakukan dengan mengidentifikasi morfologi bulu, distribusi bulu, warna ear lobe dan variasi bentuk kaki (FAO, 2012).

Usaha peternakan Kinantan Bagombak Kota Solok merupakan salah satu kandang penangkaran AKB secara $e k$-situ. Penelitian ini bertujuan untuk mengidentifikasi beberapa marka kualitatif (morfologi bulu, distribusi bulu, warna ear lobe dan variasi bentuk kaki) pada $A K B$.

\section{METODE}

Pada penelitian ini digunakan sampel AKB jantan dewasa sebanyak 50 ekor. Jumlah sampel sesuai dengan rekomendasi FAO (2012) bahwa untuk karakterisasi sifat kualitatif pada ternak unggas dibutuhkan sampel sebanyak 10-30 ekor pada ayam jantan. Penelitian ini menggunakan metode survei dengan pengamatan secara langsung. Pengumpulan data dilakukan secara sensus pada semua $\mathrm{AKB}$ jantan yang dipelihara di kandang penangkaran Kinantan Bagombak di Kota Solok.

\section{Variabel Penelitian:}

Variabel yang diamati adalah morfologi bulu, disribusi bulu, warna ear lobe dan variasi bentuk kaki pada AKB. Morfologi bulu ayam dikelompokkan atas ayam berbulu normal, bulu terbalik (fruzzle) dan bulu kapas (silky). Distribusi bulu dikelompokkan atas ayam berbulu normal, naked neck (ayam tanpa bulu leher) dan ayam berbulu di kaki. Warna ear lobe dikelompokkan atas ayam memiliki ear lobe putih, merah dan putih kemerahmerahan. Variasi bentuk kaki dikelompokkan atas ayam berkaki normal, polidaktili (jari kaki berlebih), ayam berkaki pendek (creeper) dan ayam kerdil (dwarf) (FAO, 2012). Penelitian ini dilakukan pada usaha peternakan AKB Kinantan Bagombak Kota Solok. Penelitian dimulai dari tanggal 1 Maret 2014 sampai 1 Juni 2014. 


\section{HASIL DAN PEMBAHASAN}

Usaha peternakan AKB Kinantan Bagombak adalah usaha penangkaran ek-situ AKB. Usaha ini didirikan pada tanggal 17 Juni 2011 dan terdapat di Kecamatan Tanjung Harapan, Kota Solok. Saat ini jumlah populasi AKB di kandang Kinantan Bagombak berjumlah 524 ekor yang terdiri dari ayam jantan dewasa sebanyak 50 ekor, ayam betina dewasa sebanyak 161 ekor, ayam jantan muda sebanyak 57 ekor, ayam betina muda sebanyak 89 ekor, dan anak ayam sebanyak 167 ekor.

\section{Marfologi Bulu}

Morfologi bulu AKB di Kinantan Bagombak seluruhnya berbulu normal (Gambar 1). Morfologi bulu normal disebabkan oleh faktor genetik, yaitu oleh gen Na. AKB yang memiliki bulu terbalik dan bulu kapas tidak ditemukan di kandang penangkaran Kinantan Bagombak. Ayam bulu terbalik dipengaruhi oleh gen fruzzle (gen F), sedangkan ayam bulu kapas dipengaruhi oleh gen silky. Oleh karena itu, diduga belum ada aliran gen $\mathrm{F}$ dan gen silky pada populasi AKB di Kinantan Bagombak. AKB berbulu normal diduga merupakan dominansi gen bulu normal (gen $\mathrm{Na}$ ) yang mewaris dari nenek moyang ayam domestik, yaitu ayam Hutan Merah/Red Jungle Fowl (Weigend dan Romanoff, 2001).

\section{Distribusi Bulu}

Distribusi bulu AKB di Kinantan Bagombak seluruhnya berbulu normal. Tidak terdapat AKB tanpa bulu leher (leher gundul) dan AKB berbulu di kaki (Gambar 1). Ayam tanpa bulu leher dipengaruhi oleh ekspresi gen leher gundul (naked neck gen, Na). Oleh karena itu diduga belum ditemukan adanya aliran gen ayam leher gundul dan ayam berbulu di kaki pada populasi AKB di Kinantan Bagombak.

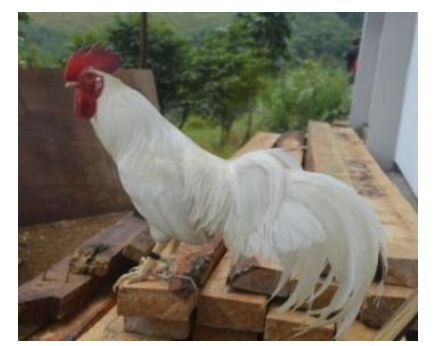

Gambar 1. AKB Bulu normal

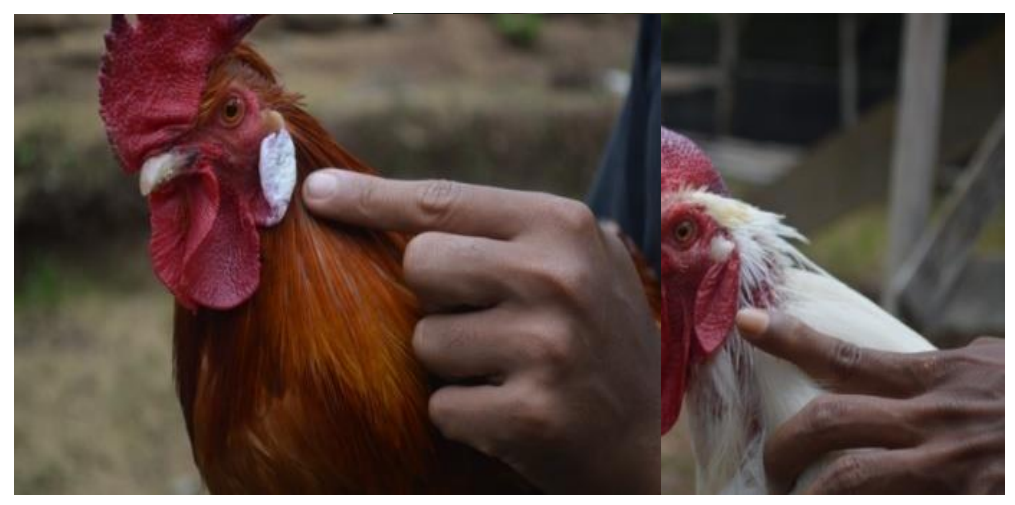

Gambar 2a. Warna Gambar 2b. Warna ear lobe putih ear lobe merah

\section{Warna Ear Lobe}

Warna ear lobe AKB di Kinantan Bagombak berturut-turut adalah merah $(74,02 \%)$, putih $(19,85 \%)$ dan putih kemerah-merahan $(6,13 \%)$ (Gambar 2). Warna ear lobe AKB berbeda dengan warna ear lobe ayam Burgo di Bengkulu. Ayam Burgo memiliki ear lobe berwarna putih (Setianto, 2013).

\section{Variasi Bentuk Kaki}

Variasi bentuk kaki AKB di kandang penangkaran Kinantan Bagombak adalah bentuk kaki normal $(94,81 \%)$ dan ayam berkaki pendek $(5,19 \%)$. AKB yang memiliki jari kaki berlebih (polidaktili) dan ayam kerdil (dwarf) tidak ditemukan di kandang penangkaran $\mathrm{Ki}$ nantan Bagombak. Ayam kerdil dipengaruhi oleh gen kerdil (dwarf), yaitu gen dw (Galal et al., 2007). Ayam berkaki pendek dipengaruhi oleh gen Creeper (gen $\mathrm{Cp}$ ), sedangkan ayam polidaktili disebabkan oleh gen polidaktili (gen Po) (Dorshort et al., 2010).

\section{KESIMPULAN}

Berdasarkan hasil penelitian dapat disimpulkan bahwa morfologi bulu dan distribusi bulu AKB di kandang penangkaran AKB Kinantan Bagombak seluruhnya berbulu normal, sedangkan warna ear lobe AKB di Kinantan Bagombak yang dominan adalah warna merah $(74,02 \%)$ dan variasi bentuk kaki AKB adalah normal $(94,81 \%)$. Sebagai pusat pengembangan AKB di Sumatra Barat, sebaiknya $A K B$ yang dipilih sebagai induk adalah AKB yang memiliki morfologi bulu 
normal, distribusi bulu normal, warna ear lobe merah dan variasi bentuk kaki normal.

\section{UCAPAN TERIMAKASIH}

Ucapan terimakasih disampaikan kepada LPPM Universitas Andalas atas bantuan biaya penelitian dalam Skim Penelitian Dosen Muda pada Tahun 2014 dengan judul penelitian "Studi Diversitas Genetik Ayam Kokok Balenggek Berdasarkan Marka Morfologis dan Bioakustik sebagai Dasar Seleksi "Ayam Penyanyi" Unggul Plasma Nutfah Sumatera Barat".

\section{DAFTAR PUSTAKA}

Dorshorst, B., R. Okimoto, and C. Ashwell. 2010. Genomic regions associated with dermal hyperpigmentation, polydactily and other morphological traits in the Silkie chicken. J. Hered. 101: 339-350.

FAO. 2012. Phenotypic Characterization of Animal Genetic Resources. FAO Animal Production and Health Paper No.11. Rome.

Fumihito., T. Miyake, M. Takada, R. Shingu, M. T. Endo, T. Gojo Baru, N. Kondo, and S. Ohno. 1996. Monophyletic origin and one subspecies of the Red Jungle Fowl (Gallus gallus gallus) dispersal patten of domestic fowl. Proc. Nat. Acad. Sci. 93:672-679.

Galal, A., A.M.H. Ahmed, U.M. Ali and H.H. Younis. 2007. Influence of naked neck gene on laying performance and some hematological parameters of dwarfing hens. Int. J. Poult. Sci. Vol. 6 Number 11.

Han, I. K. 1999. Role of animal agriculture for the quality of human life in the $21 \mathrm{st}$ century. Asian-Aust. J. Anim. Sci. 12 (5): 815-836.

Rusfidra. 2014. Recent status riset bioakustik pada ayam lokal penyanyi di Indonesia. Prosiding Seminar Nasional Perhimpunan Ilmu Pemuliaan Indonesia. Pekanbaru: Komda PERIPI Riau.
Rusfidra, S. Dt. Tan Marajo, B. Oktaveriza and Y. Heryandi. 2014a. Estimation of inbreeding rate in Kokok Balenggek chicken population under ex-situ conservation. Int. J. Poult. Sci. 13 (6): 364-367.

Rusfidra, Y.Y. Tumatra, M.H. Abbas, Y. Heryandi and F. Arlina. 2014b. Characterization of number of crow and qualitative marker of Kokok Balenggek song fowl inside a captive breeding farm in Solok Regency, West Sumatera Province-Indonesia. Int. J. Poult. Sci. 13 (6): 343-346.

Rusfidra, Y.Y. Tumatra, M.H. Abbas, Y. Heryandi dan F. Arlina. 2012. Identifikasi marka bioakustik suara kokok ayam Kokok Balenggek di kandang penangkaran "Agutalok". Jurnal Peternakan Indonesia, 14 (1): 303-307.

Rusfidra. 2004. Karakterisasi sifat-sifat fenotipik sebagai strategi awal konservasi ayam kokok balenggek di Sumatera Barat. (Disertasi, tidak dipublikasikan). Bogor: Sekolah Pascasarjana Institut Pertanian Bogor.

Setianto, J. 2013. Potensi dan strategi pengembangan ayam Burgo. Prosiding Seminar Nasional Pengembangan Ternak Lokal. Padang: Fakultas Peternakan Universitas Andalas, 20 November 2013.

Tangke, F. K, M.A. Jabbar, and B.I. Shapiro. 2000. Gender roles and child nutrition in livestock production systems in developing countries: a critical review. Nairobi, Kenya: International Livestock Research Institute (ILRI).

Van der Zijpp, A. J. 2000. Role of global animal agriculture in the $21 \mathrm{st}$ century.Asian- Aust. J. Anim. Sci. 13, Special Issue: 1-6.

Weigend, S., and M. N. Romanov. 2001. Current strategies for assesment and evaluation of genetic diversity in chicken resources. World Poult. Sci. J. 57:275-288 